\title{
IMPACT OF AGRICULTURAL EXTENSION SERVICE DELIVERY ON CASSAVA PRODUCTION IN KWAMI LOCAL GOVERNMENT AREA OF GOMBE STATE
}

\section{HARRISON Gideon Maghra and OGUNTUNDE Gabriel Ayodele (Ph.D)}

Department of Vocation and Technical Education, Adamawa State University, Mubi

Correspondence: gideonharrison7878@gmail.comTel.: +2348037013652

\begin{abstract}
The study was carried out to determine the impact of agricultural extension service delivery on cassava production in Kwami local government area of Gombe State. Four research questions and two hypotheses guided the study. The design for the study was survey. The sample for the study was 105 respondents with 93 cassava farmers and 12 agricultural extension agents. A simple random sampling technique was used to obtain the sample. The instrument for data collection was a researcher designed structured questionnaire rated on a four-point scale. The instrument was subjected to validation by 3 experts. To determine the reliability of the instrument, Pearson Product moment correlation coefficient was used after administering the instrument on a different population of farmers in Adamawa State. The coefficient obtained was 0.99. Mean and standard deviation were used to answer the research question while t-test was used at 0.05 level of significance to test the hypothesis. The findings of the study revealed that factors such as poor soil fertility among others influence cassava production in Kwami local government area of Gombe State and cassava farmers derive benefit from agricultural extension agents. The study recommended that more agricultural extension agents should be employed by the government so as to have sufficient agricultural extension service among others.
\end{abstract}

Keywords: Agricultural extension, Extension service, Agricultural extension agents, Cassava 


\section{Introduction}

In many developing countries in the world, agricultural growth is very crucial for reduction of poverty since most of the people derive their livelihood from agricultural activities which include growing of crops and rearing of animal. For agricultural production to be optimal, there is need for agricultural extension services. Agricultural extension service refers to a set of organization that support people engaged in agricultural production and facilitate their efforts to solve problems, link to markets and other players in the agricultural value chain; and obtain information, skills, and technologies to improve their livelihood (Kristin, 2009).

Agricultural extension services are used to serve as a channel for conveying and educating farmers on the new agricultural policies and practices (Nwaobiala, 2017). Furthermore, agricultural extension service is among the most common mechanisms of transferring information, knowledge and skills to farmers as support to apply the information, knowledge and skills to the real world of work (Lee, An \& Kim, 2017). The primary objectives of agricultural extension service include: providing information and educating farmers on how to apply core principles of improved technologies to farm practices. Agricultural extension services play a significant role in promoting the adoption of new technologies and innovation through communication with farmers and educating them to improve their attitude, knowledge and skills (Lawal, Torimiro \& Makanjuola, 2009). Information is key to improved agricultural production and it is the rationale for extension service delivery.

The goal of agricultural extension services in Nigeria is to facilitate acceptance by farmers while the main goal of agricultural extension is to improve the living standard of farmers through transfer of improved farming practices to the rural people (Okwoche \& Asogwa, 2012). Agricultural extension service has the capacity to improve yield of farmers. Lee, An and Kim (2017) in their study found out that agricultural extension service had significantly positive impact on crop production, gross farm revenue and profit. Inadequate extension agents hinder full exploitation of extension services in Nigeria. This is supported by the findings of Aderinto, Agbelemoge and Dada, (2017).

The success of extension service delivery depends on the expertise and technical know-how of the extension personnel, which could be achieved by providing adequate and relevant information (Nwaobiala, 2017). Agricultural extension agents are responsible for using various strategies to encourage farmers to adopt agricultural innovations. Some of the strategies include farm settlement schemes, establishment of farm institutes, experimental farms, extension work station, visit to various farms among others (Okwoche \& Asogwa, 2017).

Several extensions teaching methods are used as tools by extension workers to impart desirable changes in the behavior of farmers, provide opportunities through which important and useful communication and interaction takes place between farmers and extension workers (Nwaekpe, Anyeagbunam, Asumugha, Ekwe \& Okoye, 2014). For agricultural extension work to be optimally achieved, well trained and articulated agricultural extension workers are needed to extend extension messages to wide range of farmers who mostly live in the rural areas (Tambari, Abubakar, Attahiru \& Moyi, 2014). 
The importance of cassava as a major source of food fibre is not in doubt as it touches the lives of a large percentage of the world's population. Increase in world population leads to increase in the demand for food fibre and cassava products, with its comparative cost advantage over cereals as source of energy (Okwoche \& Asogwa, 2012). Similarly, Aderinto, Abelemoge and Dada (2017) opined that cassava is a crop with enormous potentials and it provides a stable food base for the food need of the populace, component in livestock feeds and raw materials for industries.

Nigeria like other African countries cultivates cassava on small farms to serve as a source of food for families and supply the local markets. Nigeria is the largest producer of cassava in the world with about 40 metric tonnes per annum ahead of countries like Brazil and Thailand (Awoyinka, 2009). He further noted that Nigeria is yet to fully harness the economic potentials of cassava that would translate to higher ranking of cassava next to petroleum as a major contributor to the Gross Domestic Product (GDP). Cassava is an essential food security crop because the matured edible roots can be left in the ground for 36 months and it is important not only as food crop but also as a major source of income for rural house hold (Lah, Akaba, Bosempem \& Edward, 2018).

Due to the importance of cassava as a source of food for local farmers in Nigeria, there is need for improved production of cassava which can be achieved through proper delivery of extension services. On this note, this study was conducted to determine the impact of agricultural extension service delivery on cassava production in Kwami local government area of Gombe State.

\section{Statement of the Problem}

The population of Nigeria is increasing very rapidly and there is food insecurity since most of the farmers in Nigeria today are peasant farmers and most of them are illiterates that live in rural communities. These are trends which affect their agricultural production. Some of the farmers do not adapt to new farming practices since they rely on obsolete farming practices which do not exploit their full potentials.

Research institutes such as National Root Crop Research Institute (NRCRI) Umudike and International Institute for Tropical Agriculture (IITA) Ibadan are saddled with the responsibilities of developing improved varieties of crop such as cassava and improved methods of farming. New farm practices from the research institutes do not reach farmers on time due to poor linkage between extension agents and farmers. Cassava farmers in Nigeria are not provided financial support by government or highly placed individuals in the society to improve their farming practices.

Based on the above, the study was conducted to determine the impact of agricultural extension service delivery on cassava production in Kwami local government area of Gombe State.

\section{Purpose of the Study}

The main purpose of the study was to determine the impact of agricultural extension service delivery on cassava production in Kwami local government area of Gombe State.

Specifically, the study intends to: 
- Determine the socio-economic characteristics of cassava farmers in Kwami local government area of Gombe State.

- Determine the factors influencing cassava production in Kwami local government area of Gombe State.

- Determine the information disseminated to cassava farmers by agricultural extension agents in Kwami local government area of Gombe State.

- Determine the benefits derived by cassava farmers from agricultural extension service delivery in Kwami local government area of Gombe State.

\section{Research Questions}

- What are the socio-economic characteristics of cassava farmers in Kwami local government area of Gombe State?

- What are the factors influencing cassava production in Kwami local government area of Gombe State?

- What are the information disseminated to cassava farmers by agricultural extension agents in Kwami local government area of Gombe State?

- What are the benefits derived by cassava farmers from agricultural extension service delivery in Kwami local government area of Gombe State?

\section{Hypotheses}

- There is no significant difference between the mean responses of cassava farmers and agricultural extension agents on the factors influencing cassava production in Kwami local government area of Gombe State.

- There is no significant difference between the mean responses of cassava farmers and agricultural extension agents on the type of information disseminated to cassava farmers by extension agents in Kwami local government area of Gombe State.

\section{Methodology}

The study was carried out in Kwami local government area of Gombe State which lies between latitude $8^{0}$ and $12^{\circ}$ north of equator and longitude $12^{\circ}$ and $14^{0}$ east of Greenwich meridian. Kwami local government area occupies a land mass of 121-150 square kilometer with an estimated population of 129,914 people base on 2006 census. The study area has 10 wards comprising of: Bojude, Gardam, Kwami, Kentulata, Doho, Mallamsidi, Jurara, Dubul, Malleri and Deban Fulani. The design for the study was survey research design. Structured questionnaire was used to obtain data from the respondents. A simple random sampling technique was used to obtain a sample of 105 respondents with 93 cassava farmers and 12 extension agents. The instrument for data collection was validated by 3 experts; 2 from the Department of Agricultural Education, Federal College of Education Technical, Gombe State and 1 from Adamawa State Agricultural Development Programme. The reliability of the instrument was determined using Pearson's Product Moment Correlation Coefficient on a different population. The coefficient of internal consistency was 0.99 which was closer to 1 , 
it is evident that the instrument was reliable to measure what it is expected to measure. The questionnaires were distributed personally by the researcher under the assistance of extension agents in the study area. Mean and standard deviation were used to answer the research questions while t-test statistic was used at 0.05 level of significance to test the hypotheses.

\section{Results and Discussion}

Research Question 1: What are the socio-economic characteristics of cassava farmers in Kwami local government area of Gombe State?

Table 1: Socio-economic Characteristics of Cassava Farmers in Kwami Local Government Area of Gombe State $\left(\mathrm{n}_{1}=93\right)$

\begin{tabular}{|l|l|l|}
\hline Variables & Frequency & Percentage \% \\
\hline Gender & & \\
\hline Male & 84 & 90.33 \\
\hline Female & 9 & 9.67 \\
\hline Age(Years) & & \\
\hline $18-29$ & 8 & 8.60 \\
\hline $30-39$ & 22 & 23.66 \\
\hline $40-49$ & 37 & 39.79 \\
\hline $50-59$ & 17 & 18.28 \\
\hline 60 and above & 9 & 9.67 \\
\hline Marital Status & & \\
\hline Single & 18 & 19.35 \\
\hline Married & 63 & 67.74 \\
\hline Divorced & 7 & 7.52 \\
\hline Widowed & 5 & 5.38 \\
\hline Educational Qualification & & \\
\hline No Formal Education & 69 & 74.19 \\
\hline Primary Education & 19 & 20.43 \\
\hline Secondary Education & 4 & 4.30 \\
\hline Tertiary Education & 1 & 1.07 \\
\hline Farming Experience (Years) & & \\
\hline $1-10$ & 17 & 18.28 \\
\hline $11-20$ & 29 & 31.18 \\
\hline $21-30$ & 25 & 26.88 \\
\hline 31 and above & 22 & 23.65 \\
\hline
\end{tabular}

The socio-economic characteristics of cassava farmers in Kwami local government area of Gombe State is shown in table 1 above. The result revealed that most of the cassava farmers are male $(90.33 \%)$. This finding agrees with that of Lah et al (2018) and Aderinto et al (2016). However, it is in contrast with the findings of Ogbonna and Nwaobiola (2014) who found out in their study that women dominate farming. Findings from this study further revealed that most of the cassava farmers are within the age range of $40-49$ years $(39.79 \%)$. This finding is supported by the findings of Lah et al (2018) which revealed that majority of cassava farmers are below 50years. The prospect of cassava yield increase is high due to active age of the farmers and more receptive to innovation. The study also found out that 
most of the cassava farmers are married (67.74\%). Aderinto et al (2016) and Lah et al (2018) supported this finding in their study. The few farmers that were not married were single, divorced or widowed. The output of small scale farmers can be increased if they are married and have more hands in terms of labour for production. Ayansina (2011) supported this assertion by declaring that small scale farmers could be successful if married especially when they rely on family labour. Findings on educational qualification of farmers revealed that majority of the farmers are illiterate, $74.19 \%$ of them had no formal education while $20.43 \%$, $4.30 \%$ and $1.07 \%$ had primary, secondary and tertiary education respectively. Most of the farmers had 11-20years farming experience $(31.18 \%)$ as showed by the result. Onubuogu and Onyeneke (2012) posit that more experienced cassava farmers have the possibility to know more on the problems associated with cassava production and they have high chances of overcoming these problems in yield improvement than those with little or no experience in the sector. This finding is supported by Nwaobiala (2017).

Research Question 2: What are the factors influencing cassava production in Kwami local government area of Gombe State?

Table 2: Factors Influencing Cassava Production in Kwami Local Government Area of Gombe State.

\begin{tabular}{|l|l|l|l|l|}
\hline S/N & Item Statement & $\times$ & SD & Remark \\
\hline & Poor soil fertility & 3.24 & 0.92 & Agreed \\
\hline & High cost of farm input & 3.88 & 0.64 & Agreed \\
\hline & Non-availability of market for produce & 3.15 & 0.85 & Agreed \\
\hline & Effects of pests and diseases & 2.17 & 0.89 & Disagreed \\
\hline & Inadequate finance and credit facilities & 3.19 & 0.73 & Agreed \\
\hline & Inadequate access to extension agents & 3.14 & 0.84 & Agreed \\
\hline & Lack of transportation facilities & 3.42 & 0.69 & Agreed \\
\hline & Lack of processing facilities & 3.94 & 0.87 & Agreed \\
\hline
\end{tabular}

The findings in table two above revealed the factors influencing cassava production in Kwami local government area of Gombe State. Findings showed that poor soil fertility, high cost of farm input, non-availability of market for produce among others are the factors influencing cassava production in the study area. However, respondents disagree with effects of pest and diseases as a factor influencing cassava production in the study area. Lack of processing facilities has the highest mean of 3.94 and effects of pest and diseases had the lowest mean of 2.17 .

The finding is in conformance with the findings of Aderinto et al (2017) who found out in their study that respondents had low access to possible extension service delivery and inadequate number of extension agents compared to the large number of farmers is the most severe constraint limiting full exploitation of extension services.

Research Question 3: What are the information disseminated to cassava farmers by agricultural extension agents in Kwami local government area of Gombe State? 
Journal DOI: www.doi.org/10.46654/2714

Table 3: Information Disseminated to Cassava Farmers by Agricultural Extension Agents in Kwami Local Government Area of Gombe State.

\begin{tabular}{|l|l|l|l|l|}
\hline S/N & Item Statement & $\times$ & SD & Remark \\
\hline & Information on land clearing & 2.59 & 0.57 & Agreed \\
\hline & Information on seeds/cuttings & 2.78 & 0.74 & Agreed \\
\hline & Information on planting & 3.65 & 0.57 & Agreed \\
\hline & How to control weeds & 2.80 & 0.99 & Agreed \\
\hline How to control pests & 3.12 & 1.45 & Agreed \\
\hline & How to control diseases & 3.75 & 0.82 & Agreed \\
\hline $\begin{array}{l}\text { Information on processing and storage of } \\
\text { cassava }\end{array}$ & 1.00 & 0.11 & Disagree \\
\hline Information on marketing & 3.03 & 0.13 & Agreed \\
\hline & Information on improved technology & 2.69 & 0.69 & Agreed \\
\hline
\end{tabular}

The result in table 3 above showed the information disseminated to cassava farmers by agricultural extension agents in Kwami Local Government Area of Gombe State. It revealed that information on land clearing which is the first operation that is carried out on the farm is disseminated to cassava farmers. Other information disseminated to cassava farmers include information on seeds/cuttings, planting, pests, diseases and improved technology. However, farmers are not given information on processing and storage of cassava as shown in the table. This finding agrees with the findings of Okwoche \& Asogwa (2012) who found out in their study that cassava farmers had information on marketing, pests, disease control, improved technology and agronomic practices through agricultural extension agents.

Research Question 4: What are benefits derived by cassava farmers from agricultural extension service delivery in Kwami local government area of Gombe State?

Table 4: Benefits Derived by Cassava Farmers from Agricultural Extension Service Delivery in Kwami Local Government Area of Gombe State.

\begin{tabular}{|l|l|l|l|l|}
\hline S/N & Item Statement & $\times$ & SD & Remark \\
\hline & Farming system improvement & 2.80 & 0.78 & Agreed \\
\hline & Increase in yield & 2.99 & 0.95 & Agreed \\
\hline & Increase in income & 3.04 & 0.60 & Agreed \\
\hline & Increase on standard of living & 3.00 & 0.24 & Agreed \\
\hline & Aid in marketing of cassava & 2.51 & 0.86 & Agreed \\
\hline & Financing cassava production & 1.62 & 0.98 & Disagree \\
\hline & Training on agro-technology & 2.82 & 0.52 & Agreed \\
\hline
\end{tabular}

The finding in table 4 above revealed the benefits derived by cassava farmers from agricultural extension service delivery in Kwami local government area of Gombe State. The result showed that agricultural extension service delivery has improved the farming system of cassava farmers, increase yield, income and standard of living of cassava farmers. However, respondents disagree on financing cassava production by the government. This finding is in line with the finding of Okwoche \& Asogwa (2012) who found out in their study that agricultural extension services improved the profit of cassava farmers. It is also in agreement 
with the findings of Lee, An \& Kim (2017) which revealed that agricultural extension service had a significantly positive impact on bean and rice production, gross farm revenue and income.

\section{Hypotheses Testing}

HO 1: There is no significant difference between the mean responses of cassava farmers and agricultural extension agents on the factors influencing cassava production in Kwami local government area of Gombe State.

Table 5: t-test of Difference between the Mean Responses of Cassava Farmers and Agricultural Extension Agents on Factors Influencing Cassava Production in Kwami Local Government Area of Gombe State.

\begin{tabular}{|l|l|l|l|l|l|l|l|}
\hline Respondents & Mean & SD & N & df & t.cal & t.crit & Remark \\
\hline Cassava farmers & 3.24 & 1.27 & 93 & & & & \\
Extension agents & 3.28 & 1.49 & 12 & & 1.31 & 1.98 & Accept \\
\hline
\end{tabular}

The hypothesis above tested at 0.05 level of significance showed that $\mathrm{t}$-calculated is 1.31 which is less than the t-critical value of 1.98 . This showed that the null hypothesis was accepted which means that there is no significance between the mean responses of cassava farmers and agricultural extension agents on the factors influencing cassava production in Kwami local government area of Gombe State.

HO 2: There is no significant difference between the mean responses of cassava farmers and agricultural extension agents on the type of information disseminated to cassava farmers by extension agents in Kwami local government area of Gombe State.

Table 6: t-test of Difference between the Mean Responses of Cassava Farmers and Agricultural Extension Agents on the Type of Information Disseminated to Cassava Farmers by Extension Agents in Kwami Local Government Area of Gombe State.

\begin{tabular}{|l|l|l|l|l|l|l|l|}
\hline Respondents & Mean & SD & N & df & t.cal & t.crit & Remark \\
\hline Cassava farmers & 2.40 & 1.37 & 93 & & & & \\
\cline { 1 - 5 } Extension agents & 2.43 & 1.74 & 12 & & 0.72 & 1.98 & Accept \\
\hline
\end{tabular}

The above hypothesis tested at 0.05 level of significance revealed that the value of $t-$ calculated 0.72 is less than the value of t-critical 1.98. Therefore, the null hypothesis is accepted which means that there is no significant difference between the mean responses of cassava farmers and agricultural extension agents on the type of information disseminated to cassava farmers by agricultural extension agents in Kwami local government area of Gombe State. 


\section{Conclusion}

Based on the results of this study, the following conclusions were made:

The study determined the impact of agricultural extension service delivery on cassava production in Kwami local government area of Gombe State. It is clear based on the results of the study that factors such as poor soil facility, pests and diseases, lack of processing facilities among others influence cassava production in Kwami local government area of Gombe State. It is also evident in the study that cassava farmers have access to information on cassava from agricultural extension agents.

Furthermore, it is evident in this study that cassava farmers derive benefits from agricultural extension agents in form of information ranging from cultural practices for cassava production to improved technology which in turn improve their yield, income and standard of living.

\section{Recommendations}

The following recommendations were made based on the findings of this study:

- More agricultural extension agents should be employed by the government to have sufficient agricultural extension services.

- Government should provide farm inputs to farmers at a subsidized rate.

- Farmers should make proper usage of the information disseminated to them to improve their production. 


\section{References}

Aderinto, A., Agbelemoge, A. \& Dada, O. M. (2016). Effectiveness of Extension Service Delivery and Productivity of Cassava Farmers in Southern Nigeria. The Journal of Agricultural Sciences. Vol. 12 No. 1. pp14-23. http:dx.doi.org/10.4038/jas.vl2i1.8202

Awoyinka, Y. A. (2009). Cassava Marketing Option for Sustainable Agricultural Development in Nigeria. Ozean Journal of Applied Science. Vol. 2 (2) pp 175-183.

Ayansina, S. O. (2011). Farmers Perception of Public and Private Extension Services. A case Study in South Western Nigeria (Doctoral Thesis). University of Ilorin, Nigeria. Unpublished.

Kristin, E. D. (2009). The Important Role of Extension Systems. Agriculture and Climate Change. An Agenda for Negotiation in Copenhagen. International Food Policy Research Institute 2033K Streat, NW. Washington D.C 20006-1002. USA Focus 16. BriefII.

Lah, M. K., Akaba, S., Bosempem, M. \& Edward, M. (2018). Public and Private Extension Services Delivery to Cassava Farmers in Sanniquellie and Saclepea Mahn Districts in Nimba Country, Liberia. Journal of Sustainable Development in Africa. Vol. 20 No. 1. pp64-86.

Lawal, B. O., Torimiro, D. O. \&Makanjuola, B. A. (2009). Impact of Agricultural Extension Practices on Nigeria Poultry Farmers' Standard of Living. A Perceptional Analysis. Tropical and Subtropical Agroecosystem 10:265-473.

Lee, Y., An, D. \& Kim, T. (2017). The Effects of Agricultural Extension Service on Farm Productivity: Evidence from Mbale District in Uganda. Preprints (www.preprints.org) doi:1020944/preprints 201704.0162.v1

Nwaekpe, J. O., Anyeagbunam, H. N., Asumugha, G. N., Ekwe, K. C. \& Okoye, B. C. (2014). Challenges to the Effectiveness of Extension Methods Adopted byNational Root Crops Research Institute for Agricultural Technology Dissemination in South East Nigeria. Proceedings of the $48^{\text {th }}$ Annual Conference of the Agricultural Society of Nigeria, Abuja 2014. pp. 93-97.

Nwaobiala, C. U. (2017). Effect of Agricultural Extension Delivery Methods on Arable Crop Farmers' Cropping Systems in Kaduna State, Nigeria. Scientific Papers Series Management, Economic Engineering in Agriculture and Rural Development vol.17 issues pp 225-230.

Okwoche, V. A. \& Asogwa, B. C. (2012). Impact of Extension Services on Cassava Farming in Benue State, Nigeria. International Journal of Business, Humanities and Technology.Vol2No.6pp89-98.

Onubuogu, G. C. \& Onyeneke, R. U. (2012). Market Orientation of Root and Tuber Crops Production in Imo State, Nigeria. Agricultural Science Research Journal. Vol.2(5), pp.206-216.

Tambari, I. W., Abubakar, B. Z., Attahiru, M. \&Moyi, S. S. (2014). Strengthening the Capacity Building of Extension Workers of Sokoto Agricultural Development Project Towards Enhancing Agricultural Transformation Agenda in Nigeria. Proceedings of the $48^{\text {th }}$ Annual Conference of the Agricultural Society of Nigeria. Abuja 2014. Pp578-581. 